\title{
Teaching methods in primary school
}

\author{
Comparison of approach in the Czech Republic and Spain
}

\author{
Martin Skutil \\ Institute of Primary and Pre-primary Education \\ Faculty of Education, University of Hradec Králové \\ Hradec Králové, Czech Republic \\ martin.skutil@uhk.cz
}

Abstract - The paper presents partial results of a comparison in educational approaches at primary schools in the Czech Republic and Spain. The attention is devoted to the use of teaching methods in practice, specifically in the subjects of National History and Geography. This is a descriptive study, which is mainly based on observations and interviews. It is therefore a qualitative-quantitative grasp of the problem. It turns out that in both countries the emphasis is given to group work, but there are also considerable differences based on current trends of both educational systems. This paper was written in the context of a specific research project realised with the support of the Faculty of Education, University of Hradec Králové.

Keywords-primary education; teaching methods; comparative study; national history and geography

\section{INTRODUCTION}

Currently many educational systems around the world are undergoing transformation. In addition to finding the optimal way to an efficient educational process based on curriculum innovation at all levels, one of the main features is also a transformation of the real educational process. One of the main principles is the implementation of constructivist elements into teaching, which gradually replace the traditional transmissive approach to education. This is mainly reflected in the transformation of teaching methods utilisation in education, which in lay far more emphasis on the co-operative elements in education and preference of a pupil's individuality.

From this perspective, an irreplaceable role is played by teachers who are smuggled into the role of facilitators and training guides, instead of the traditional roles of information carriers. If a school is supposed to prepare Pupils for the Purposes of the Principle of lifelong learning and lifelong education, teachers must use droughts Approaches That Will Develop the intellectual and memory components in students, as well as the emotional component. This is helped by the selection of the appropriate AIM of teaching methods that arouse a student's interest in the subject matter and motivate them for further education and self-education [1].

The process cannot manage without teaching methods as they form its main core together with the content and aim of teaching. The course and effectiveness of the method could be disturbed by the environment, in which teaching is realised. We try to form a pleasant atmosphere and climate in the class. It is necessary for the teacher to master the wildest spectrum of teaching methods and suitably and functionally use them. Only in this way will teaching becomes effective [2].

\section{THEORETICAL BASIS}

According to Maňák and Švec [3], a teaching method represents "a dynamic element" in teaching, which compared with the content and organisational forms changes relatively rapidly and adapt to new circumstances and objectives. The teaching methods, however, are not the decisive determinant of teaching, but only one of the elements of the educational system, and therefore cannot replace the missing content and compensate the indistinct target. On the contrary, they are tied to the overall concept of teaching and only within it are they fully functional and effective. Many other authors, e.g. Harmer [4], Storch [5] or Scrivener [6]. talk about teaching methods in the same way, according to whom a teaching method is a teaching specifically didactic activity of the subject and object of teaching, developing the educational profile of a student, while acting educationally, in terms of training and educational objectives and in accordance with teaching and educational principles. It lies in the modification of content, directing the activity of subject and object, organisation of the sources of knowledge, techniques and procedures, ensuring fixation or control of knowledge and skills, cognitive attitudes, interests and processes [7].

The ideal subject, where it is possible to make full use of both classic and modern material resources, is the teaching of National History and Geography. The content of this subject is based on the Framework Education Programme for Basic Education [8], namely the educational area of Humans and the world, while this area consists of topics like The Place Where We Live, People around Us and People and Time. National History and Geography include geographic and historical curriculums. The geographical curriculum follows on the knowledge of natural science. Pupils move their observations from the closest area of residence and school to geographic observations of their region, the Czech Republic and Europe. They learn about neighbouring countries, their natural conditions, economic and social advancement. They search major European cities and tourist centres on maps and acquire basic knowledge of the process of European unification. In the historiographical curriculum pupils learn about significant personalities and historical stages of our national history, they learn to classify the main events into centuries, they acquire basic historiographical concepts associated with the organisation of society [9].

\section{RESEARCH METHODOLOGY}

The research realised is based on a qualitative-quantitative survey. I chose this combination mainly because the aim is not 
only to describe the ways of working, but also to understand why teachers approach teaching in the selected way. I follow the design of Miles and Huberman presented by Flick [10]. Standard methodological approaches were used for data processing $[11 ; 12]]$

\section{A. Research Tool}

For the quantitative part based on the observation, we chose a standardised evaluation tool targeted at teaching methods and forms prepared by Žák [13]. This tool has the character of a criteria record, which is based on the categorisation of teaching methods and forms. It defines eight teaching methods (with an optional category of "other methods") and three organisational forms of teaching (with an optional category of "other forms"). The tool has three basic parts - characteristics of each method and form of teaching; an inspection sheet; discussion section. The inspection sheet contains a table for basic information about teaching, a scale with two defined degrees and a table which lists the specific methods and forms. There is also an opportunity to indicate other than those listed methods and forms, if they occurred. The discussion should lead to a structured reflection of teaching in terms of forms and methods, and outline ways to work with methods and forms of teaching in the future.

\section{B. Research Group}

Intentionally, the research groups were selected so that they are the same in size. They are municipal schools of approximately the same size so the external environment effect on the way of work is the most eliminated. They are traditional schools whose curriculum corresponds to the general trends in education in both monitored countries. The schools are located in the city of Hradec Králové in the Czech Republic and in the city of Valencia in Spain. The reason for comparison of the Czech and Spanish approaches was motivated by the possibility to realise a research survey in both countries.

- In the Czech Republic, a total of 15 teaching units have been observed and a total of 15 subsequent interviews with teachers were carried out.

- In Spain, a total of 15 teaching units have been observed and a total of 15 subsequent interviews with teachers were carried out

\section{SELECTED RESEARCH FINDINGS}

There are many categorisations of teaching methods which are based on different principles. To interpret the results, it was necessary to adhere to one of them. In the Czech Republic, the most established category is the one from Maňák and Švec [3], so I will follow it in the subsequent interpretation.

TABLE I. USE OF TEACHING METHODS

\begin{tabular}{|l|c|c|}
\hline & Czech Republic & Spain \\
\hline $\begin{array}{l}\text { Traditional } \\
\text { methods }\end{array}$ & $42 \%$ & $39 \%$ \\
\hline Activating methods & $28 \%$ & $23 \%$ \\
\hline $\begin{array}{l}\text { Comprehensive } \\
\text { methods }\end{array}$ & $30 \%$ & $38 \%$ \\
\hline
\end{tabular}

In terms of education, both countries surveyed use the teaching methods in almost the same way.

Traditional teaching methods include for example interpretation, explanation, work with text or conversation. In the Czech Republic, these methods are represented by $42 \%$, which is three percentage points more than in Spain. It is not a significant difference, but it is possible, within other outcomes, to consider this result to be an interesting one (see Table II).

Activating teaching methods are designed to involve pupils more in the educational process. In particular, these methods are discussion, heuristic or didactic games. Here again the Czech Republic is slightly ahead, the result is 5 percentage points higher. The result is not significantly different.

The largest percentage difference - $8 \%$ - between the two compared countries is within the category of comprehensive teaching methods. They include for example project teaching, brainstorming, group teaching, teaching in everyday situations, etc. It is obvious that this category is more represented in Spanish schools. In connection with the following table it is understandable why this is the case.

TABLE II. ORGANISATIONAL FORMS OF TEACHING

\begin{tabular}{|l|c|c|}
\hline & Czech Republic & Spain \\
\hline Individual work & $21 \%$ & $13 \%$ \\
\hline Group work & $28 \%$ & $39 \%$ \\
\hline Collective teaching & $51 \%$ & $48 \%$ \\
\hline
\end{tabular}

There is a noticeable difference especially in the use of individual and group work. While individual activity is increasingly represented in the Czech Republic, on the contrary, in Spain a greater emphasis is laid on group work. Involvement of collective teaching is roughly the same in both investigated countries, i.e. around $50 \%$ of the time.

TABLE III. GROUP VERSUS COOPERATIVE TEACHING

\begin{tabular}{|l|c|c|}
\hline & Czech Republic & Spain \\
\hline Group teaching & $76 \%$ & $74 \%$ \\
\hline Cooperative teaching & $24 \%$ & $26 \%$ \\
\hline
\end{tabular}

Within the observation the attention was also paid to the fact whether group or co-operative education is used more. Both school systems in their curricula emphasise co-operative elements in teaching, for this reason I also find it interesting to note this result.

It turns out that in both countries group activity significantly predominates. Although teachers often talk about co-operative activities, in practice they are more often implemented in the form of group work. One of the reasons often stated by teachers is less time-consuming in checking and evaluating activities in group work compared to co-operative teaching, when time demands are considerably higher. From my personal point of view, however, there is one more affecting element - teachers' terminological ignorance of the difference between the two principles, which was found out in the analyses of lessons within discussions. 
TABLE IV. USE OF ICT IN EDUCATION

\begin{tabular}{|l|c|c|}
\hline & Czech Republic & Spain \\
\hline Every day & $13 \%$ & $7 \%$ \\
\hline $2-3 x$ per week & $42 \%$ & $26 \%$ \\
\hline $\begin{array}{l}\text { Approximately1x per } \\
\text { week }\end{array}$ & $33 \%$ & $35 \%$ \\
\hline Less often & $12 \%$ & $32 \%$ \\
\hline
\end{tabular}

One of modernisation elements in teaching is undoubtedly the implementation of modern technology into teaching. The transformation of education systems often leads to situations where modernisation of the curriculum is the perception of belonging to technologisation of education.

Here it is possible to observe more significant differences and motives of the teachers in each country. While in the Czech Republic the teachers are more open, see [2], Spanish teachers are sceptical towards modern technology, and according to their statements they prefer to put more emphasis on the socialisation of children through co-operative activities. This does not mean, however, that they would resign to become familiar with modern technologies. On the contrary Czech teachers perceive the use of modern technology as an incentive for further education and attractiveness of educational activities.

\section{CONCLUSIONS}

Of course I am aware of the limitation of the presented results and methodological limits of this study, whether in terms of the size of the research groups in both countries and the limitations associated with the selection of schools only in two locations. Despite this, I believe that the data obtained may be an interesting starting point for further, more intensive and broader research surveys from the category of general didactics or comparative pedagogy.

Leaving aside the formal differences, such as the length of primary education and internal structure of primary education, approaches to the teaching of young school children are similar to a significant degree in the Czech Republic and Spain.

With regard to transformation of the educational system based on constructivist and humanistic principles, teaching in both countries is implemented with the aim at a child and with effort of their development in connection with the idea of lifelong learning and lifelong education.

One manifestation of these principles is the transformation of the approach towards the education of children in the form of selecting other teaching methods and organisational forms in teaching. Larger emphasis is given not only to the development of the individuality of each individual, but also to their ability to work within a team.

These principles are evident from the selected research results mentioned in this paper. It turns out that both countries are moving in the same direction in the concept of education. From the interviews after the observations, however, it was revealed that teachers in Spain place more emphasis on group activities rather than on individual skills. The reason for that will be the subject of further investigation.

With regard to the use of teaching methods, no major differences were discovered. A significant difference was found only in comprehensive teaching methods, which represent the practices more focused on collective activities, which essentially corresponds to the findings of the organisational forms of teaching category.

Significant differences were found in the use of modern technology in teaching. Here, the Czech Republic dominates quite significantly. Although Spanish schools have adequate equipment, it must be admitted that technologisation of schools in the Czech Republic is at a considerably high level, as well as the qualifications of teachers to work with ICT. Likewise, the motivation of teachers in the Czech Republic for the use of ICT in teaching is higher than those of teachers in Spain. This corresponds to the findings presented.

\section{ACKNOWLEDGMENT}

This paper was written as part of a specific research project of the Faculty of Education, University of Hradec Králové No. 2107/2014 Analysis of education process from usage of teaching methods point of view.

\section{REFERENCES}

[1] M. Skutil, "View of primary education in terms of the application of teaching methods in the educational process focusing on project based teaching" 7th International Conference of Education, Research and Innovation - ICERI2014, November 2014, pp. 6437-6443. (Article in a conference proceedings )

[2] M. Skutil, "ICT as one of the teaching methods at primary school from a teacher's point of view", Problems of Education in the 21 st Century, 2014; vol. 61, issue 61, pp- 105-112.

[3] J. Maňák and V. Švec, Teacing methods [Výukové metody]. Brno: Paido, 2003.

[4] J. Harmer, How to teach English. England: Addison Wesley Longman Limited, 1998.

[5] G. Storch, Deutsch als Fremdsprache-Eine Didaktik. München: Wilhelm Fink Verlag, 1999.

[6] J. Scrivener, Learning Teaching. Oxford: Macmillan Publishers Limited, 2005.

[7] M. Skutil, K. Hvalíčková and R. Matějičková, "Educational process in terms of teaching methods and organisational forms in small schools", INTE 2014 Conference proceedia (in press).

[8] Framework Educational Programme for Elementary Education. Praha: VÚP, 2007.

[9] M. Skutil, K. Hvalíčková and R. Matějíčková, "Didactic Material Resources in the Teaching of National History and Geography: Selected Results of a Qualitative Survey", World academy of science, engineering and technology, October 2013, vol. 82, pp. 1153-1157. (Article in a conference proceedings )

[10] U. Flick, Designing Qualitative Research. London: SAGE, 2007.

[11] D. Silverman, Interpreting qualitative data: methods for analyzing talk, text, and interaction. London: SAGE, 2006.

[12] S. Gorard, Quantitative Methods in Educational Research. London: Continuum,. 2001.

[13] V. Žák, Teacing methods and Organizational forms of education: observation sheet of paper [Metody a formy výuky: hospitační arch]. Praha: Národní ústav pro vzdělávání, 2012. 